\title{
Information Transfer and Press Coverage: The case of the Gawler Craton Gold Boom
}

\author{
Andrew Ferguson ${ }^{\mathrm{a}, *}$, Adrian Crockett ${ }^{\mathrm{b}}$ \\ ${ }^{a}$ School of Accounting, University of Technology, Sydney, Broadway NSW 2007, Australia \\ ${ }^{b}$ Liability Strategies Group, Deutsche Bank AG, London, EC2N 2DB,UK
}

\begin{abstract}
This study examines intra-industry information transfer after Helix Resources NL announced a successful drill result in the Gawler Craton region of South Australia, which sparked significant investor interest in mining companies with tenement holdings in the area. This study shows the price response of competing explorers was determined by press coverage immediately following the discovery of gold, but stocks that received most press attention in the immediate post announcement period suffered greatest longterm underperformance. The research is the first in capital market literature to make use of geographical information systems software technology.
\end{abstract}

JEL classification: G12; G14

Keywords: Information Transfer; Real Options; Press Coverage; Geographical Information Systems; Behavioural Finance

\footnotetext{
${ }^{*}$ Corresponding author. Tel.: +61-2-9514-3576; fax: +61-2-9514-3669.

E-mail address: andrew.ferguson@uts.edu.au (A.Ferguson).

\# This paper does not express the views of Deutsche Bank AG or any of its associated parties.
} 


\subsection{Introduction}

This paper examines the case of a famous gold discovery in South Australia made by Helix Resources NL. The discovery saw Helix's share price rise from 45 cents on the close of trading one day prior to the initial announcement on the November $18^{\text {th }} 1996$, to $\$ 3.70$ at the close of trading on November $27^{\text {th }} 1996$, a $722 \%$ increase in just eight trading days. The issue we address is whether the wealth effects attributable to competing explorers with tenement interests in the area arose from information transfer, and / or news coverage.

We find that initially press coverage drove returns, but stocks that received most press attention suffered the greatest long-term underperformance one-year post discovery. This result might be interpreted two ways. First, the results might imply market over-reaction stemming from complex information coupled with limited disclosure, an exotic location, and the existence of substantial news coverage. Alternatively, the results can be interpreted in a rational real options context. On balance, our evidence is more consistent with the latter interpretation.

Our findings can be compared with those of Niederhoffer (1971), who finds investor over-reaction to newspaper headlines, as well as to those of Lang and Lundholm (2000), who find that increased positive disclosure prior to a Seasoned Equity Offering (SEO) results in post-offering underperformance. The study also provides a fascinating contrast with DeAngelo and DeAngelo (1998), who find case evidence that press coverage influenced resource allocation in an important political debate involving the primary industry in the United States. 
The remainder of this paper is structured as follows. In Section 2, we review the information transfer literature, and Section 3 examines literature concerned with the impact of news coverage on the capital market. Sections 4 and 5 contain a review of our testable propositions and research methodology. Section 6 and 7 contain the results and conclusions of the study.

\subsection{Theoretical Background}

According to Brown (1994), "information transfer refers to the process by which information conveyed to the market about one firm, the announcing firm, conveys value relevant information about other non-announcing firms, usually confined to related firms or firms within the same industry." Dietrich (1989) suggests that information transfer studies assume that firm specific information disclosures have industry-wide implications.

Prior empirical work on information transfer has evolved in two main areas. For example, Firth (1976), Clinch and Sinclair (1987), and Baginski (1987) have examined the existence, duration and magnitude of financial information transfer effects. Studies of non-financial information transfer effects include Bowen et al. (1983), Olsen and Dietrich (1985) and Dranove and Olsen (1994) ${ }^{1}$. This study develops the non-financial information transfer line of inquiry initiated by these authors and is the first study to use Australian data. We also extend the information

\footnotetext{
${ }^{1}$ Bowen et al. (1983) studies the effects of the announcement of the Three Mile Island mishap, Olsen and Dietrich (1985) examine the impact of information transfer between retailers and suppliers following retail sales announcements, and Dranove and Olsen (1994) examine the share price impacts on pharmaceutical companies following firm specific dangerous drug announcements.
} 
transfer literature by focussing on the extractive industry. Work in this area is valuable given the economic significance of the extractive industries in Australia ${ }^{2}$.

Most prior literature on information transfer has dealt with earnings announcements. For example, Firth's (1976) findings indicate that the stronger the price effects of the announcement on the announcing firm, the stronger the information transfer among firms within the industry. Share price adjustments of nonannouncing firms were also completed quite quickly, with negligible price effects observed beyond the announcement date. Firth's (1976) findings about the speed of adjustment of non-announcing firms hold some implications for this study. Earnings announcements are released on a regular basis and are likely to be more easily understood by the majority of market participants. Most investors will easily ascertain whether an earnings figure represents 'good news' or 'bad news' and will make adjustments to future earnings expectations accordingly. For this reason the pricing implications of earnings announcements can be quickly incorporated into the pricing of similar firms within an industry.

In contrast, mining companies' announcements of drilling results involve nonfinancial information, which can be very difficult to interpret. Mineral company disclosures routinely include discussion of complex variables such as metal purity (or

\footnotetext{
${ }^{2}$ For example, in Australia around the time of the discovery in December 1996 there were 431 listed mining companies out of a total of 1212 listed companies, or $36 \%$ of total listed companies were mining companies. This figure excludes all companies in mining services and engineering industries which directly rely on the mining industry for much of their commerce. Source: Who Audits Australia 1997.
} 
the metallic grade in grams per tonne for precious metals, or percentage for base metals), the width of the drilling intercepts, and the depth below the surface where the intercept occurs. Highly technical factors also come into play when seeking to assess the valuation implications of such disclosures. These include the geochemical composition of the mineralisation of the discovery, which impacts on metal recovery rates and ore processing $\operatorname{costs}^{3}$. Other complexities include the proximity of the discovery to mine infrastructure such as power and water supplies.

Two implications of this complexity are: (i) investors may need more time to successfully estimate the value implications of any discovery, and (ii) more purely speculative activity by traders who hold little geological expertise and trade only on the basis of press reports is likely to occur. We next discuss prior literature dealing with studies examining the role of press coverage in the capital markets.

\subsection{Capital Market literature relating to Press Coverage}

Given the availability and extent of media coverage in our lives today, it is somewhat surprising that more research has not been conducted on the impact of media on stock market actors and their investment allocation decisions ${ }^{4}$. In one earlier study, Neiderhoffer (1971) provides evidence that world events depicted in newspaper headlines impact stock prices. The headlines vary in importance according to their width in columns, depth in inches and size and boldness of the type used.

\footnotetext{
${ }^{3}$ An example of such geochemical complexity is the Mt Olympus project owned by Sipa Resources

NL. This project had attractive resource estimates and gold grades, but was deemed sub-economic due to geochemical problems with extracting the gold from the mineralisation.

${ }^{4}$ Jensen (1976) provides some interesting background reading on the demand and supply of 'news'.
} 
Neiderhoffer (1971) finds that the greater the importance of the headline, the larger the impact on stock prices. Interestingly, his evidence indicates that on days 2-5 following extremely bad world events stock prices rise. Niederhoffer (1971) attributes this to an overreaction to bad news. Our study by contrast, examines market reaction to a substantive good news event.

DeAngelo and DeAngelo (1998) illustrate the effects of press coverage on resource allocation ${ }^{5}$. Their study examines the case of the Pacific Lumber Company in the United States. This company acquired logging rights to a Redwood forest in California. The subsequent media depictions of an 'environmental crisis' that would occur if the trees were felled precipitated presidential intervention through acquisition of the forest from the company by the government. The acquisition price constituted a sum many times the commercial value of the lumber. DeAngelo and DeAngelo (1998) suggest that:

"The Pacific Lumber (PL) case shows how society sometimes allocates property rights and resolves externality conflicts not through the rational weighting of social costs and benefits, but via a media dominated perceptions game." (p5).

\footnotetext{
${ }^{5}$ Another well-known U.S. case of the impact of hype is the Orange Juice Freeze in Florida in late 1989. Record low temperatures led to sharply reduced crop estimates and sent orange juice futures prices soaring. Much hype focussed on freeze implications for juice prices and the 'crisis' facing producers. The share price of the NYSE listed Orange-Co Inc (NYSE: OJ) fell 18\% from prices prior to the onset of the freeze. In reality however, OJ had little exposure to the freeze. Since its head office was in Florida the perception was the company was badly affected. In reality, PR newswire (16.01.90) reported that "the company benefited from the diversity of its orange groves, as they are primarily located south of the freeze line".
} 
and,

"The Pacific Lumber case illustrates (1) how a misreading of economic facts can take on a life of its own when reported by enough credible and apparently independent media sources, and (2) how the public's resultant erroneous perceptions can have substantial resource implications for firms and for society as a whole.” (p29)

DeAngelo and DeAngelo (1998) is relevant to the Gawler Craton as both cases focus on the natural resource industry and both attracted substantial media coverage.

Finally, the recent paper by Lang and Lundholm (2000) provides a clue to possible post discovery long-term price behaviour for our sample. Lang and Lundholm (2000) do not examine press coverage specifically, but study the disclosure practices of firms engaged in SEO's. They observe that firms increasing the number of positive disclosures in the six months prior to the SEO announcement obtain share prices increases. However, upon the announcement of the SEO, these firms suffer much larger price declines. Lang and Lundholm (2000) suggest that these positive disclosures may have been a way of "hyping" the stock ${ }^{6}$.

\footnotetext{
${ }^{6}$ We sought to examine whether any of our press reports constituted 'hype'. To do this, two expert raters consisting of two Professors, one who has published internationally in the area of content analysis, and the other a Professor of geology, independently rated the press reports using a dictionary definition of press coverage. 'Hype' could exist in either the headline, the body of the press report or both. Using Holsti (1969) an inter-rater reliability was calculated using the formula: $C R=\frac{2 D}{(N+M)}$

Where: $\mathrm{D}$ is the number of coding decisions on which the two coders were in agreement, $\mathrm{N}$ and $\mathrm{M}$ the number of decisions made by the two coders respectively. A score of .74 was obtained, indicating a good level of agreement between the two raters on what constituted 'hype'. Articles where
} 
While the link between positive company disclosures and positive press reporting is not assumed, the findings of Lang and Lundholm (2000) may be indicative of what might be observed in terms of long-term post discovery price performance. Their findings suggest that the initial burst of publicity around the discovery might precipitate price increases that reverse following the initial bout of euphoria.

\subsection{Proposition Development}

We utilised an inductive approach to gain insights about how competing explorer share prices would respond to successful drilling announcements. To do this, we conducted interviews with senior resource analysts and broking staff from three leading broking houses in Sydney and Melbourne ${ }^{7}$. At the commencement of each interview, we briefly described the case of the Helix's discovery in South Australia. Each resource analyst or broker was readily familiar with the case, and specific details of the case appeared to be widely known among the investment community.

The subjects were then asked for their opinions on what drove competing explorers prices following the discovery. A consensus of opinion was reached on four consistent factors described as determinants of the share price responsiveness of competing exploration firms to the Helix discovery announcement. These four factors included the extent of press coverage attributable to each competing explorer, the

disagreements between the raters occurred were randomly included or excluded. However, the reported results are not sensitive to classification of press reports as media hype. 
spatial distance of the competing explorers' tenements from the Helix discovery location, and the number and area of those tenements. The identification of these specific factors was consistent with our expectations based on prior mineral discoveries. In Australia, for example, a press frenzy accompanied the Poseidon boom, and the Kambalda nickel boom in the late 1960's and early 1970's. Some useful discussion of this case can be found in Sykes $(1978)^{8}$. Sykes (p.350) suggests:

"The Sydney evening newspapers were later widely criticised as 'tip sheets' during the boom."

and,

"There was certainly a great deal of inaccurate information reported in the press during the boom."

A more recent case example of the importance of tenement spatial proximity is the Mining Project Investors Pty Ltd (MPI) discovery at Silver Swan in Western Australia, where recent insider trading allegations have been brought against a former employee of the high profile J.B.Were stockbroking firm ${ }^{9}$. The employee ordered 266,000 shares in the publicly listed Mount Kersey Mining NL for a client while aware of the significant mineral discovery made on an adjacent mining tenement owned by MPI (a private company). This information was at that stage not publicly

\footnotetext{
${ }^{7}$ The interview process included the running of a pilot interview with a director of one of these broking houses prior to interviewing the resource analysts.

${ }^{8}$ Sykes (1978) also documents surrounding tenement holders around Mt Windarra in April 1970, suggesting the importance of tenement spatial proximity.

${ }^{9}$ See front page of Business section, Sydney Morning Herald 22 ${ }^{\text {nd }}$ August 1998 p 93.
} 
disclosed ${ }^{10}$. The following day when the MPI discovery was announced, the share price of Mount Kersey opened at $\$ 0.70$ and closed at $\$ 1.40$ illustrating the significant valuation implications of tenement proximity.

Two further factors were raised in our interviews with industry participants where consensus of opinion could not be reached ${ }^{11}$. The first factor was firm size ${ }^{12}$. The second factor was the impact of the Gold price. This suggestion is interesting in light of Tufano (1998) who analyses the exposure of North American gold firms to changes in the gold price, and Moel and Tufano (2002), who model gold mine closure as a function of gold prices amongst other factors. In light of these prior studies, it is worth contextualising the discovery in terms of metal prices at the time. The London

\footnotetext{
${ }^{10}$ This case illustrates disclosure anomalies between ASX listed stocks and non listed entities not subject to the same ASX reporting requirements.

${ }^{11}$ Our subjects also discussed the infamous example case of the Bre-X Minerals saga at the Busang project in Indonesia. The Bre-X project had some similarities with Helix discovery in the Gawler Craton: both projects were located in areas not previously subject to extensive exploration, both were situated in exotic locations including the outback of South Australia and the forests of Borneo, and there are disclosure anomalies evident in both cases. The Bre-X Minerals Busang site was according to the Economist "cloaked in unusual secrecy, and few people outside the company were allowed in". Whilst there is no implication of wrongdoing in the case of Helix, there existed no publicly available national database of tenement locations at the time of the discovery. These factors may indicate contexts in which investors are more reliant on the media for information which may or may not be erroneous.

${ }^{12}$ We run sensitivities for firm size in the regression model. Inclusion of firm size does not alter tenor of reported results. For example, when size is included in the event window model, the size $t$ statistic is $.52(p=.61)$. In this model, all other previously significant predictors when size is excluded remain significant when size is included.
} 
PM fix on November $18^{\text {th }}$ was $\$$ US 379.10 . At November $27^{\text {th }}$, the date of the second announcement, Gold fixed at \$US 373.00 after falling for 6 out of seven trading sessions. This trend in gold prices indicates that the returns on stocks during the discovery event window in our sample were not likely to be driven by fluctuations in the gold price, particularly fluctuations on the upside.

In summary, four factors were identified from induction. These factors are distinguishable in terms of investor 'rationality'. The first factor, press coverage is associated with an 'irrational' response ${ }^{13}$. The three alternative factors, tenement area, number of tenements, and the spatial location of those tenements are all associated with 'rational' or efficient investor responses. We therefore utilise two competing propositions: The first proposition is that investors responded to news reports. The second is that investors responded to rational factors. These propositions are described further in the following sections.

\subsection{Proposition 1 - Irrationality: Press reports}

We examine the effects of the intensity of press reporting on share price returns on both announcement dates and the intervening time period between announcements ${ }^{14}$. The press coverage proxy is measured by extracting the total number of print media articles in Reuters Business Briefing and ABIX over the event window for companies in the sample discussing the Gawler Craton ${ }^{15}$. Press coverage

\footnotetext{
${ }^{13}$ We also test the possibility that press coverage was used rationally in section 6.2.1.

${ }^{14}$ Refer to timeline - Figure 1 in section 6.1.1

${ }^{15}$ Reuters Business Briefing - On-line real time information database, ABIX - Australian Business Intelligence on Disk.
} 
is simply the number of company specific citations included in these news reports. The first propositions is:

The greater the competing company's exposure to press coverage following the discovery, the greater its share price response to Helix's discovery.

\subsection{Proposition 2 - Rationality: Tenement spatial location, size and number}

Discussion with participants at the broking houses revealed that the physical distance of the competing exploration firm's tenement portfolio from Helix's tenements, the competitors tenement area and their numbers of tenements are expected to impact competitors' stock price reactions. The closer a competing explorer's tenements to the discovery location, the higher the probability that its tenements will contain ore. Similarly, the larger the area of the competing explorers tenements, the greater the probability of exploration success. Finally, the greater the number of tenements in the Gawler Craton, the higher the probability that they might also find an economic resource ${ }^{16}$. Therefore, our second proposition is:

\footnotetext{
${ }^{16}$ The merit of these assertions is shown by the increase in Gawler Craton provincial exploration expenditure post discovery, which shows a $223 \%$ increase in Gawler Craton provincial exploration from 1996 to 1997 . This percentage also includes one and a half months of post discovery increase included in the 1996 data (Source - PIRSA). The increase indicates the desirability of undertaking exploration in the area in light of the increased probability of success.
} 
The greater the size, and number and proximity of the competing firms' exploration tenements to Helix Tenement 2028, the stronger its share price responsiveness to Helix's discovery announcement ${ }^{17}$.

In the study, distance is calculated two ways as depicted in Appendix $1^{18}$. First, we calculate the centroidal distance or the distance from the centre of Helix tenement 2028 to the centre of the competing explorer's tenement. Second, the closest distance measure is calculated by finding the shortest distance between the Helix tenement 2028, and the competing explorer's tenement. We also calculate average distances for companies with more than one tenement to give an average distance for the entire tenement portfolio. Calculations using both the above distance methodologies are facilitated using the polygon topology shapefiles and spider plots generated by Arcview 3.0 software ${ }^{19}$.

\footnotetext{
${ }^{17}$ Some principles from the real estate finance and economics literature might also be relevant here. For example, Dubin (1998) and Basu and Thibodeau (1998) find evidence of spatial autocorrelations between the prices of neighbouring houses and property submarkets. In addition, Thorsnes and McMillen (1998) find evidence consistent with the value size or higher value for increased land parcel size relationship.

${ }^{18}$ The Arcview shapefile polygon tenement topography in Appendix 1 depicts a longer line from the centre of Helix Tenement number 2028 to Pasminco Tenement 2011 showing a distance between tenement centroids or centroidal distance of $105.612 \mathrm{kms}$. The shorter line depicts the closest distance between these two tenements, a distance of just $45.267 \mathrm{kms}$. As expected, all four alternate distance measures are positively correlated at .76 or better, significant at $p<.01$

${ }^{19}$ Arcview 3.0 is an established GIS package produced by the Environmental Systems Research Institute (ESRI) based in Redlands California.
} 


\subsection{Experimental Design and Research Method}

\subsection{Data}

We acquired mineral tenement data from the Primary Industry and Resources South Australia (PIRSA) effective from the day prior to the initial announcement by Helix $^{20}$. This database included every mineral tenement holder at the close of trading one day prior to announcement date. Not every company with mineral tenements is a listed company, so only those companies traded on the ASX were included in the study. Every listed firm was identified from the PIRSA database and included in our analysis, indicating that our sample is the population of listed organisations. The PIRSA database also provided details of tenement area and perimeter that provided the basis for calculation of spatial distances using ArcView Software as discussed in section 4.2 .

Share price, trading volume and index performance (All Ordinaries and All Mining Index) are sourced from Bloomberg. This data source has the advantage of containing adjusted share prices controlling for dividends, stock splits and other capital raisings. Risk data was acquired from the Centre for Research in Finance (CRIF) located at the Australian Graduate School of Management (AGSM).

\subsection{Sampling}

The database received from PIRSA contained a total of 286 mineral tenements. 133 entities held interests in these tenements. Of these firms, 101 were unlisted companies and 32 were listed. It was also necessary to analyse non-listed firms to

\footnotetext{
${ }^{20}$ Formerly Mines and Energy South Australia (MESA).
} 
establish whether or not the company was a subsidiary of a listed company. Utilising Jobsons Mining Yearbook 1996/1997 that contains a "directory of subsidiaries", an additional 21 firms that were subsidiaries of listed companies were identified. A number of these were originally identified as listed companies originally, e.g., Acacia Resources a listed company also had tenements licensed to Acacia Metals Pty Ltd. After eliminating duplication amongst subsidiaries we identified 41 firms listed on the ASX.

Finally, it was necessary to identify whether any other listed mining firms had "farmed into ${ }^{21 "}$ exploration tenements or entered into joint ventures with other mining companies with licences in the Gawler Craton. We undertook analysis of all firms undertaking farm-ins or joint ventures prior to the announcement date using ASX's Datadisc. We identified a further 4 firms, two of which were already included in our sample. This process resulted in a final sample of 43 listed Australian companies ${ }^{22}$. Data from both Bloomberg and CRIF were complete which ensured no reduction of our sample through data attrition.

\subsection{Methodology}

The case study methodology is employed, however this case study is unique, as it incorporates empirics to examine the price effects of the drilling result

\footnotetext{
${ }^{21}$ The process of "farming into" an exploration permit refers to payments made by a prospective explorer to an extant tenement licensee who relinquishes equity in a tenement in return for either cash payments, expenditure on project development, a production royalty, a net smelter return or a combination of these. 'Farminees' were identified from Huntleys Datanalysis.

${ }^{22}$ Company names and ASX codes available from authors upon request.
} 
announcements made by Helix Resources on November $18^{\text {th }} 1996$ and a subsequent exploration update announcement on the November $27^{\text {th }}$. The focus of the study is on the value implications of these announcements on every ASX listed firm engaging in exploration in the Gawler Craton at the time of the initial announcement ${ }^{23}$.

The case lends itself to empirical analysis for a number of reasons. For example, the Gawler Craton region was distinctive because of limited prior mineral exploration in the area. In fact Helix's exploration manager Tony Martin in a presentation at the prestigious 1997 Diggers and Dealers conference in Kalgoorlie, Western Australia suggested that one of the features that attracted Helix to the area in the first place was "limited previous exploration." A reason for this was that the area was almost completely covered by alluvial sediments, which according to Martin meant that:

"Exploration of the region could not rely solely on the use of geophysics but would require systematic geochemical coverage including extensive drilling to be effective ${ }^{24,}$

The lower expenditure on prior exploration implies that the market was less familiar with the province as a whole. This suggests the Helix discovery occurred within a unique setting - a new and largely unexpected discovery with little prior information upon which to base future economic expectations.

\footnotetext{
${ }^{23}$ This empirical component of the study draws on the event study methodology. The combination of the case study and event study methodologies is novel.

${ }^{24}$ Martin and Mosig (1997) p. 2
} 
In addition, the Helix announcement to the stock exchange on November $18^{\text {th }}$, and the subsequent exploration update announcement on November $27^{\text {th }}$ were standalone announcements on exploration in the Gawler Craton. Both announcements were made independently of regular quarterly reporting requirements to the ASX, and therefore were not contaminated by other value relevant exploration details or financial information. Both announcements were also made prior to the market opening at 10.00am. From an analytical point of view, these circumstances are ideal, as returns will reflect the announcement information and not trading noise arising prior to an intra-day announcement reflected in the daily return. In addition, the market had a full day's trading to digest the information, which would not have been the case if the announcement were made intra-day.

The dual announcements facilitate four periods for empirical analysis. The first period is simply Announcement 1 on the $18^{\text {th }}$. The second analysis period is an intervening period from the $19^{\text {th }}$ to the $26^{\text {th }}$. The third analysis period is the second announcement date on the $27^{\text {th }}$. The last period is simply the entire event from the $18^{\text {th }}$ to the $27^{\text {th }}$. (A simple event time line can be viewed in Fig. 1 in section 6.1.1).

\subsubsection{Return calculation}

The formula for abnormal returns for firm $i$ over event window $(i, t)$ is simply ${ }^{25}$ :

$$
A R_{i, t}=\left[\frac{P_{i, t}-P_{i, t-1}}{P_{i, t-1}}\right]-\left[\frac{R_{a m i, t}-R_{a m i, t-1}}{R_{a m i, t-1}}\right]
$$

\footnotetext{
${ }^{25}$ We make market model adjustments to Equation 1 with little or no impact on reported results.
} 
where:

$\mathrm{AR}_{i, t}$ is the abnormal return of firm ${ }_{i}$ at time ${ }_{i}$;

$\mathrm{P}_{i, t} \quad$ is the share price of firm $_{i}$ at time ${ }_{t}$;

$\mathrm{P}_{i, t-1}$ is the share price of firm $i$ at time $\mathrm{t}_{t-1}$

$\mathrm{R}_{\mathrm{a} m i, t}$ is the level of the All Mining Index at time ${ }_{t}$; and

$\mathbf{R}_{\text {ami, } t-1}$ is the level of the All Mining Index at ${ }_{t-1}{ }^{26}$.

Abnormal returns over the event window $(\mathrm{p}, \mathrm{q})$ are summarised by CAR calculations as follows:

$\operatorname{CAR}_{i, t}(p, q)=\sum_{t=p}^{q} A R_{i, t}$

\subsubsection{Regression Equation}

We utilise the following OLS regression equation to examine the validity of the two propositions in Sections 4.1 and 4.2

CAR $_{i, t}=\beta_{0}+\beta_{1}$ DISTANCE $_{i, t}+\beta_{2}$ AREAS $_{i, t}+\beta_{3}$ NUMTEN $_{i, t}+\beta_{4}$ PRESS $_{i, t}+e_{i}$

where:

$\mathrm{CAR}_{i t} \quad$ is the Cumulative Abnormal Return of firm ${ }_{i}$ at time ${ }_{i}$;

DISTANCE $_{i t}$ is the shortest distance from Helix Tenement number 2028 to the closest of firm $i$ 's tenements ${ }^{27}$;

\footnotetext{
${ }^{26}$ The All Ordinaries Index over the event window commenced on the $18^{\text {th }}$ at 2383.8 and closed on the $27^{\text {th }}$ at 2376.7 , a fall of $.003 \%$. The All Mining Index commenced at 951.5 on the $18^{\text {th }}$ and closed at 933.5 on the $27^{\text {th }}$, a fall of $1.89 \%$. Thus the Gawler Boom occurred during a steady market index, and a slightly lower mining index. We utilize the All Mining Index, and run a sensitivity test using the All Ordinaries Index, but results are not sensitive to choice of industry or market indices.
} 
NUMTEN $_{i t}$ is the number of tenements that firm $i$ holds in the Gawler Craton one day prior to the initial announcement;

AREA $_{i t}$ is the average area of firm $i$ 's tenement portfolio in the Gawler Craton; and

PRESS $_{i t}$ is the number of company specific citations for firm $i$ in articles referencing the Gawler Craton sourced from Reuters Business Briefing and ABIX.

$\mathrm{e}_{i} \quad$ is a normally distributed error term.

\subsection{Results}

\subsection{Summary statistics}

Panel A of Table 1 depicts the descriptive statistics. The Distance variable is calculated as the distance in meters from the competing explorers closest tenement to tenement number 2028. The average distance from the discovery zone is 179.283 kilometres. The maximum distance is 670.515 kilometres and logically a zero minimum occurs for adjoining tenement holders. Abnormal returns on November $17^{\text {th }}$ (one day prior to the initial discovery) are negligible, but are significant on the discovery announcement date on the $18^{\text {th }}$ and during the intervening trading window from the $19^{\text {th }}$ to the $26^{\text {th }}$. This is also visible in Fig. 1 in section 6.1.1. The second announcement date on the $27^{\text {th }}$ also exhibits strong abnormal returns.

\footnotetext{
${ }^{27}$ Sensitivities show results vary little running tests using the alternative distance methodologies as well as summing distances to get an average portfolio distance figure using alternative distance methodologies.
} 


\section{[Insert Table 1 here]}

Univariate analysis depicted in Panel B of Table 1 indicates positive and significant relationships exist between press coverage and returns for each of the four time periods with correlation co-efficients of $.36, .32, .35$ and .47 over the eight day event window (all co-efficients are significant at $p<.05$ or better). In addition, the distance proxy is negatively related to CAR's on each occasion, and over the event window, the co-efficient is $-.37(p<.05)$. Examination of the independent variables indicates few have significant relationships with each other. Nevertheless, we performed variance inflation factor analysis (VIF) on each regression model. Nearly all of our VIF's were less than two, limiting concern over multicollinearity ${ }^{28}$.

\subsubsection{Partition of sample into press coverage and no press coverage portfolios}

In Table 2, we partition the sample into those companies receiving press attention, and those companies experiencing no press coverage over the event window. ' $\mathrm{T}$ ' tests of means and Mann Whitney tests of ranks between the two portfolios indicate companies receiving press coverage maintained significantly higher returns over the event window. Also of note in Table 2 is the rough equivalence of the two portfolios in terms of risk, with the mean beta for the press portfolio of 1.42 , slightly lower than the mean of 1.63 for the non-press portfolio.

[Insert Table 2 here]

\footnotetext{
${ }^{28}$ VIF's are calculated based on the $\mathrm{R}^{2}$ from regressing independent variables on each other. According to Kennedy (1992) a VIF in excess of ten indicates problematic multicollinearity.
} 
Fig. 1 details the Gawler Craton time line, indicating the initial and subsequent announcement dates and the intervening period. Fig. 1 graphically portrays the differences between the performance of the two portfolios with mean abnormal returns attributable to the press portfolio in excess of 50\% compared with $12 \%$ for the no press portfolio over the event window.

\section{[Insert Figure1 here]}

\subsection{Multivariate analysis}

Table 3 reports results of OLS regression models after running the White heteroskedasticity correction procedure. The tests utilise the shortest distance measure $^{29}$. The first four columns under Panel B of Table 3 indicate the incremental effects of press coverage after this variable is added to the tests based solely on rational predictors (Panel A). All four models including press coverage are significant with adjusted $\mathrm{R}^{2}$ s ranging from .10 to .35 , with $F$ values significant at $p<.10$ or better.

Excluding for the moment the post event model reported in the final column of Panel B, each event period model obtains greater explanatory power where press coverage is included ${ }^{30}$. All significant coefficients except for number of tenements carry the hypothesised sign using two tailed tests. The finding on tenement numbers

\footnotetext{
${ }^{29}$ Selection of alternative distance methodologies, and focus on closest tenement or tenement portfolio do not alter the tenor of results.

${ }^{30}$ Heirarchical regression tests of the rational model over the entire event window indicate a significant change in $\mathrm{R}^{2}$ in the model following the inclusion of press coverage at $p<.01$
} 
implies the market was more concerned about the location of tenements as opposed to provincial tenement holdings per say. The insignificant finding on tenement area supports this assertion.

[Insert Table 3 here]

The distance co-efficient is negative for each post-announcement model and is significant in each case except the first announcement. The co-efficient for press coverage is positive and significant at $p<.05^{31}$ or better for models except for the intervening time period between from November $19^{\text {th }}$ to the $26^{\text {th }}$. These findings suggest that while press coverage initially moved prices at announcement 1 , price responses after this time were also driven by rational factors ${ }^{32}$. Thus, the incremental explanatory power generated by press coverage may indicate the market used press coverage as an informing mechanism. An interesting question remains about the mix of traders relying on this information and what informed and uninformed traders learned from the press reports.

\footnotetext{
${ }^{31}$ All tables report two tailed tests. For the intervening time period (November $19^{\text {th }}-26^{\text {th }}$ ) press coverage is significant at $p=.055$ using a one tailed test, $(p=.11 \mathrm{using}$ a two tailed test, is not significant).

${ }^{32}$ Removal of outliers based on standardised residuals exceeding three standard deviations from the mean indicates reported results are not driven by inclusion of outliers.
} 


\subsubsection{Stock price changes in a real options context}

One interesting possibility is that these stock price changes might rationally be viewed in a real options context ${ }^{33}$. Since press coverage was greater for firms with landholdings closer to the strike zone, investors not knowing the probabilities of exploration success on surrounding tenements may have simply bought the portfolio of firms 'in the news', with the rational expectation that a small number of subsequent successful exploration efforts would produce adequate in-the-money outcomes to compensate for a blanket exposure trading strategy. The price increase in this setting relates to the premium on the call for the real option, and the subsequent decline depicting the realisation of option expiry out of the money.

To test this possibility, daily share price data was acquired from the SIRCA core research database for a one-year period following the second announcement. Issued capital was also acquired from the Huntleys Datanalysis file ${ }^{34}$. To simulate the value of an option over a one-year term, we construct market capitalisation at monthly intervals post event. The decline in median market capitalisation over the year reflects the reduced probability of option expiry in the money, and subsequent option expiry. Interestingly, the median press coverage market capitalisation around a one year option expiry is nearly identical to the control no press portfolio. This is depicted in Fig. 2.

\section{[Insert Figure 2 here]}

\footnotetext{
${ }^{33}$ We are grateful to an anonymous reviewer for this suggestion, and note relevance of this approach given the application by Moel and Tufano (2002) of real options theory to gold mine closure decisions in North America.
} 
An OLS regression model is then run to test for the incremental effects of press coverage on price performance one-year post discovery after controlling for rational disappointment (ie rational predictors). This model is displayed in the last column of Panel B in Table 3. The model including rational variables and press is significant and obtains an adjusted $\mathrm{R}^{2}$ of .148. As might be expected, post discovery performance is most strongly related to press coverage (co-efficient negative and significant at $p<.01$ )

Thus, it appears that after controlling for rational disappointment, the rise and fall in press portfolio seems at least partially explained in a rational setting. Under this interpretation, press coverage served as a conduit or an informing mechanism for rational high variance traders who purchased the press portfolio as an option over future exploration and possible discovery in the region. The dissolution of value in the press coverage portfolio simply reflects the rational disappointment and decreased probability of subsequent discovery of economic mineralisation. Advocates of this position would suggest the negative effects of press coverage in the post event period imply that press coverage simply encapsulates rational disappointment.

A second view is that press coverage misinformed, and that the Gawler case represents an example of euphoric overreaction. Supporting this case is the significance of press coverage during and after the event, and the post-event insignificance of the distance coefficient. However the technical nature of a good proportion of the news reports, and the options simulation evidence tend to weaken this interpretation.

\footnotetext{
${ }^{34}$ SIRCA - Security Industry Research Corporation Asia Pacific
} 


\subsection{Summary and Conclusions}

This paper has examined what drove abnormal returns generated by competing explorers following a well-known mineral discovery in South Australia. Our findings have two possible interpretations. First, the stock price changes seem explainable in a real options pricing context. In this context, press coverage informed high variance traders about prospectivity in the region. These rational traders responded by purchasing options over future discoveries with higher probability of subsequent discovery assigned to the firms attracting press coverage.

Supporting this interpretation is the technical nature of the commentary in many of the news reports, which suggests that rational agents were 'informed' as opposed to 'misinformed'. Further evidence of rationality is depicted in the close tracking of the press portfolio to the Helix market value post-event, supporting an interpretation consistent with stock price changes occurring in a real options context. This finding cautions against immediate assumptions of 'irrationality' in such circumstances. Other examples of seeming over-reaction including the 'new economy' phenomena would make interesting follow up.

A second possibility is that press coverage had dual effects - it acted as an informing mechanism, as well as misinforming depending on the sophistication of the trader. This suggests the case may illustrate strategies or mechanisms that both informed and uninformed traders utilise to interpret complex non-financial information, and potential differences in interpretation of news among traders with differing levels of information. If uninformed traders were the primary users of the press, it issues a cautionary note on dependence on news for trading information, 
especially in a context of poor disclosure, an exotic location and a complex information release.

The complexity of geological information and the fact that no national tenement databases were publicly available suggests that uninformed traders may have been more reliant on media reports, if the overreaction proposition is to be believed. This is consistent with Zucker (1978) who finds that the less experienced individuals are with an issue, the more they rely on the print media for information. Future research might be directed at partitioning on investor sophistication, which may assist uninformed traders make better future decisions.

The study also documents an important disclosure issue. The MPI case (footnote 9) indicates disclosure anomalies existing in the distinction between public and private companies may need to be examined. Finally, we also contribute the first successful deployment of Geographical information systems (GIS) technology in a capital markets setting. Combining interdisciplinary technology platforms and theory with the financial economics literature seems an interesting field for future enquiry.

\section{[Insert Appendix 1 here]}

\section{Acknowledgements}

We wish to particularly thank an anonymous referee, Dr Malcolm Humphries, CEO of Compass Resources NL, Mr David Timms, CEO of Golden Cross Resources NL, and Jerry Zimmerman, Russell Lundholm, Graham Partington, Zoltan Matolscy, 
Janet Seitsma, Michael Kean, and Peter Wells along with participants at the 1999 AAANZ and 2001 AFBC conferences. The authors acknowledge assistance from ESRI Australia Limited and feedback from interviews at Hartley Poynton Ltd, CS First Boston Ltd, and Dicksons Ltd. Mr Russell Bird from PIRSA is also thanked, along with Stephen Kean, whose valuable research assistance is acknowledged.

\section{References}

Baginski, S.P., 1987. Intra-industry information transfers associated with management forecasts of earnings. Journal of Accounting Research 25 (2), 196-216.

Basu, S., and Thibodeau, T.G., 1998. Analysis of spatial autocorrelation in house prices. Journal of Real Estate Finance and Economics 17 (1) 61-85.

Bowen, R., Castanias, R., and Daley, L., 1983. Intra-Industry effects of the accident at Three Mile Island. Journal of Financial and Quantitative Analysis 18, 87-111.

Brown, P., 1994. Capital markets based research in accounting: An introduction. Coopers and Lybrand Accounting Research Methodology Monograph No. 1, Coopers and Lybrand and AAANZ.

Clinch, G.J., and Sinclair, N.A., 1987. Intra-Industry information releases: A recursive systems approach. Journal of Accounting and Economics 9 (1) 89-106.

Craswell, A., 1997. Who audits Australia? Accounting and Finance Foundation, University of Sydney. 
DeAngelo, H., and DeAngelo, L., 1998. Ancient redwoods and the politics of finance: The hostile takeover of the Pacific Lumber Company. Journal of Financial Economics 47 (1) 3-53.

Dranove, D., and Olsen, C., 1994. The economic side effects of dangerous drug announcements. Journal of Law and Economics 37 (2) 323-348.

Dubin, R.A., 1998. Predicting house prices using multiple listings data. Journal of Real Estate Finance and Economics, 17 (1) 35-59.

Firth, M., 1976. The impact of earnings announcements on the share price behaviour of similar type firms. The Economic Journal 86, 296-306.

Holsti, O.R., 1969. Content analysis for the social sciences and humanities, Addison Wesley, Reading, MA.

Jensen, M.C., 1976. Towards a theory of the press. Economics and Social Institutions $267-287$.

Jobsons Mining Year Book 1996/97 1996. Dun \& Bradstreet Marketing, Sydney.

Kennedy, P., 1992. A Guide to Econometrics, $3^{\text {rd }}$ ed. Cambridge, MA: The MIT Press. 
Lang, M, and Lundholm, R.L., 2000 Voluntary disclosure and equity offerings: Reducing information asymmetry or hyping the stock? Contemporary Accounting Research Winter. 623 - 663.

Martin, T., and Mosig, R., 1997. Tunkillia and Beyond. Paper presented at the Diggers and Dealers Forum, Kalgoorlie July $29^{\text {th }}$.

McConnell, J., and Muscarella, C.J., 1985. Corporate capital expenditure decisions and the market value of the firm. Journal of Financial Economics 14, 399-422.

Moel, A., and Tufano, P., 2002. When are real options exercised? An empirical study of mine closings. Review of Financial Studies 15, 35-64.

Niederhoffer, V., 1971. The analysis of world events and stock prices. Journal of Business 44 (2) $193-219$.

Olsen, C., and Dietrich, R.J., 1985. Vertical information transfers: The association between retailers' sales announcements and suppliers' security returns. Journal of Accounting Research 23 (Supp) 144-166.

Sykes, Trevor., 1978. The Money Miners, Wildcat Media, Sydney.

Thorsnes, P., and McMillen, D.P., 1998. Land value and parcel size: A semiparametric analysis. Journal of Real Estate Finance and Economics. 17 (3) 233-244 
Tufano, P., 1998. The determinants of stock price exposure: Financial engineering and the Gold mining industry. Journal of Finance 53, 1015-1052.

Zucker, H.G., 1978. The variable nature of news media influence. Communication Yearbook No. 2, Rubin, B.D. (ed) New Jersey: 225-245. 


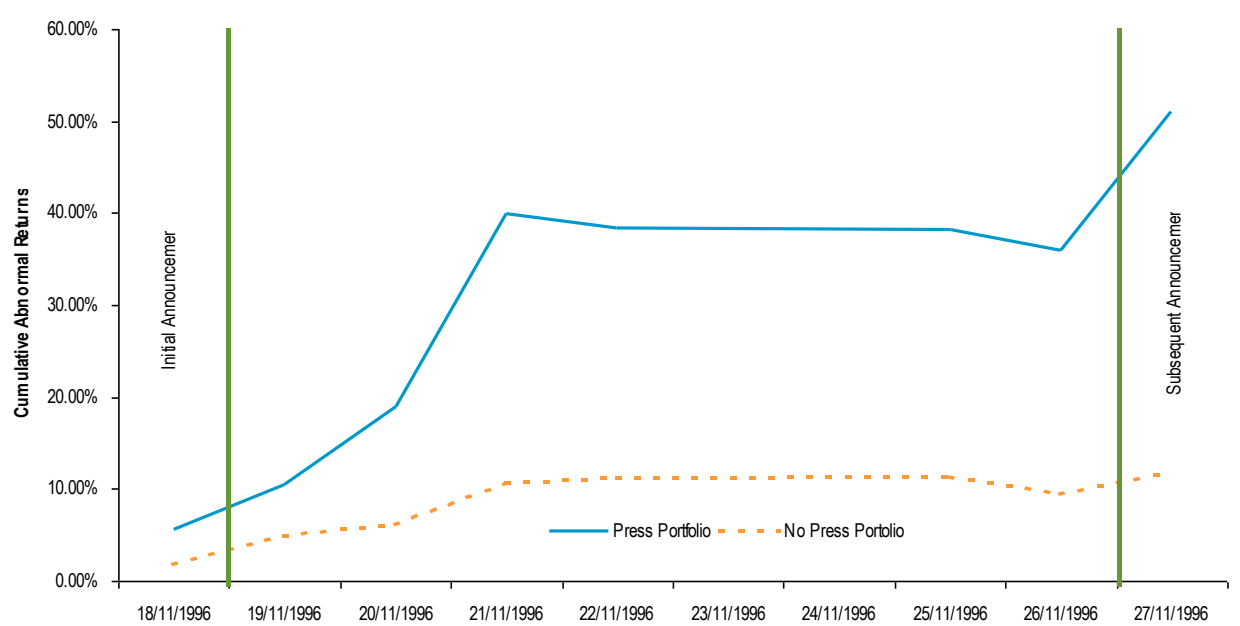

Fig. 1. Performance of press and no press porfolio over the 8 day event window 


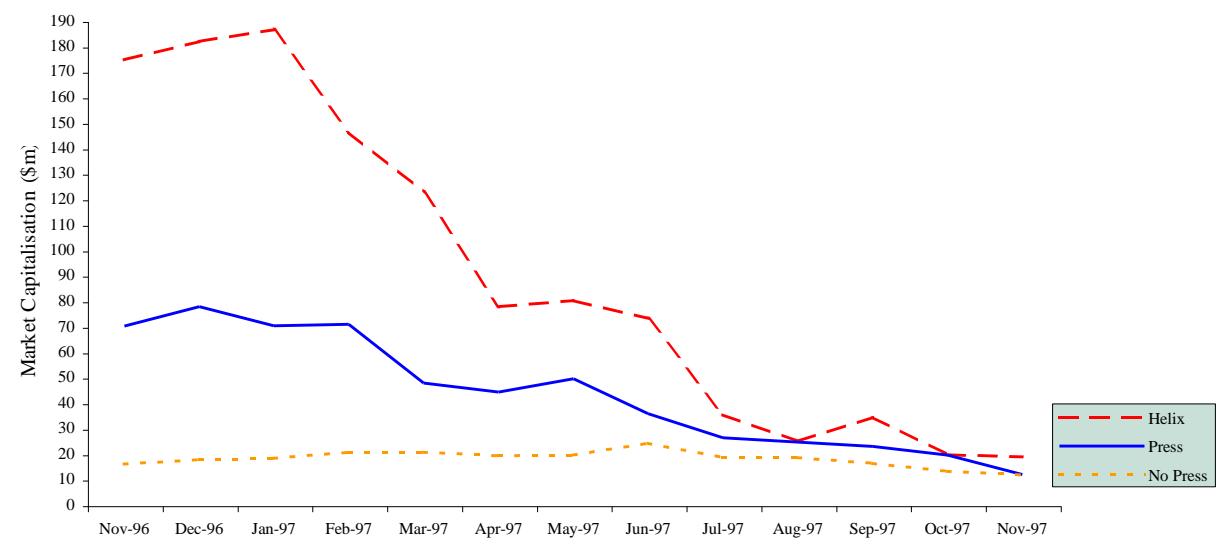

Fig. 2. Helix market capitalisation and one year post event option simulation for the press coverage portfolio based on median portfolio market capitalisation. 
Table 1 - Summary Statistics

\begin{tabular}{|c|c|c|c|c|c|c|c|c|c|c|c|c|}
\hline \multirow[t]{2}{*}{ PANEL A } & \multicolumn{10}{|c|}{ Descriptive statistics } & & \\
\hline & \multicolumn{2}{|c|}{ MEAN } & MEDIAN & \multicolumn{2}{|l|}{ ST.DEVIATION } & MINIMUM & MAXIMUM & \multicolumn{2}{|c|}{ SKEWNESS } & KURTOSIS & & \\
\hline CAR 17 & \multicolumn{2}{|c|}{0.00} & -0.01 & 0.05 & & -0.08 & 0.17 & & 59 & 3.38 & & \\
\hline CAR 18 & \multicolumn{2}{|c|}{0.04} & 0.01 & 0.08 & & -0.05 & 0.36 & & 34 & 6.57 & & \\
\hline CAR 19-26 & \multicolumn{2}{|c|}{0.20} & 0.01 & 0.47 & & -0.14 & 2.73 & & 04 & 19.79 & & \\
\hline CAR 27 & \multicolumn{2}{|c|}{0.09} & 0.01 & 0.15 & & -0.06 & 0.60 & & 64 & 2.25 & & \\
\hline CAR 18-27 & \multicolumn{2}{|c|}{0.33} & 0.05 & 0.62 & & -0.17 & 3.33 & & 11 & 12.75 & & \\
\hline SIZE & \multicolumn{2}{|c|}{1567059.67} & 10791.00 & 5531320.83 & & 831.00 & 35230000.0 & & 67 & 34.52 & & \\
\hline AREA & \multicolumn{2}{|c|}{2579.11} & 658.63 & 4561.19 & & 1.12 & 18692.16 & & 35 & 4.83 & & \\
\hline NUMTEN & \multicolumn{2}{|c|}{4.93} & 3.00 & 4.64 & & 1.00 & 16.00 & & 25 & 0.30 & & \\
\hline DISTANCE & \multicolumn{2}{|c|}{179283.00} & 145554.00 & 162874.00 & & 0.00 & 670515.00 & & 19 & 0.85 & & \\
\hline PRESS 18 & \multicolumn{2}{|c|}{0.16} & 0.00 & 0.69 & & 0.00 & 4.00 & & 87 & 24.87 & & \\
\hline PRESS 19-26 & \multicolumn{2}{|c|}{4.35} & 1.00 & 6.83 & & 0.00 & 23.00 & & 59 & 1.27 & & \\
\hline PRESS 27 & \multicolumn{2}{|c|}{0.19} & 0.00 & 0.66 & & 0.00 & 3.00 & & 87 & 14.64 & & \\
\hline PRESS 18-27 & \multicolumn{2}{|c|}{4.67} & 1.00 & 7.43 & & 0.00 & 25.00 & & 58 & 1.23 & & \\
\hline \multirow[t]{2}{*}{ PANEL B } & \multicolumn{12}{|c|}{ Pearson Product-moment correlation co-efficients } \\
\hline & CAR 18 & CAR 19-26 & CAR 27 & CAR $18-27$ & SIZE & AREA & NUMTEN I & DISTANCE & PRESS 18 & PRESS 19-26 & PRESS 27 & PRESS 18-27 \\
\hline CAR 18 & 1.00 & & & & & & & & & & & \\
\hline CAR 19-26 & .13 & 1.00 & & & & & & & & & & \\
\hline CAR 27 & $.59^{\mathrm{a}}$ & $.73^{\mathrm{a}}$ & 1.00 & & & & & & & & & \\
\hline CAR $18-27$ & $.37^{\mathrm{b}}$ & $.96^{\mathrm{a}}$ & $.88^{\mathrm{a}}$ & 1.00 & & & & & & & & \\
\hline SIZE & -.10 & -.12 & -.17 & -.14 & 1.00 & & & & & & & \\
\hline AREA & -.09 & .12 & .23 & .14 & .03 & 1.00 & & & & & & \\
\hline NUMTEN & .19 & -.21 & -.04 & -.15 & .27 & -.16 & 1.00 & & & & & \\
\hline DISTANCE & -.27 & -.30 & $-.44^{\mathrm{a}}$ & $-.37^{\mathrm{b}}$ & -.08 & -.23 & $-.44^{\mathrm{a}}$ & 1.00 & & & & \\
\hline PRESS 18 & $.36^{\mathrm{b}}$ & .14 & .24 & .21 & -.07 & -.01 & -.01 & -.22 & 1.00 & & & \\
\hline PRESS 19-26 & $.61^{\mathrm{a}}$ & $.32^{\mathrm{b}}$ & $.65^{\mathrm{a}}$ & $.48^{\mathrm{a}}$ & -.11 & .02 & $.40^{\mathrm{a}}$ & $-.51^{\mathrm{a}}$ & $.53^{\mathrm{a}}$ & 1.00 & & \\
\hline PRESS 27 & .19 & .06 & $.35^{\mathrm{b}}$ & .15 & -.04 & .26 & -.10 & -.19 & .14 & .28 & 1.00 & \\
\hline PRESS $18-27$ & $.61^{\mathrm{a}}$ & $.31^{\mathrm{b}}$ & $.65^{\mathrm{a}}$ & $.47^{\mathrm{a}}$ & -.11 & .04 & $.36^{*}$ & $-.51^{\mathrm{a}}$ & $.59^{\mathrm{a}}$ & $.99^{\mathrm{a}}$ & $.36^{\mathrm{b}}$ & 1.00 \\
\hline
\end{tabular}

Notes:

$\mathrm{CAR}=$ Cumulative abnormal returns on November $17^{\text {th }}, 18^{\text {th }}, 19^{\text {th }}-26^{\text {th }}, 27^{\text {th }}$ and $18^{\text {th }}-27^{\text {th }}$ respectively

SIZE $=$ Total assets for 1996. (For December year end companies we use the December 95 figure)

AREA=Sum of tenement areas scaled by number of tenements

NUMTEN=Number of mineral tenements

DISTANCE $=$ The shortest distance of firms closest tenement to tenement number 2028

PRESS $=$ Citations in news articles on November $18^{\text {th }}, 19^{\text {th }}-26^{\text {th }}, 27^{\text {th }}$ and $18^{\text {th }}-27^{\text {th }}$ respectively

${ }^{\text {a }}$ Significant at the $1 \%$ level

${ }^{\mathrm{b}}$ Significant at the $5 \%$ level 
Table 2 - Partition of sample by press coverage

\begin{tabular}{|c|c|c|c|c|c|c|c|c|c|}
\hline \multicolumn{4}{|c|}{ Press Portfolio } & \multicolumn{4}{|c|}{ No Press Portfolio } & \multirow{2}{*}{$\begin{array}{c}\text { Means } \\
\text { 'T' test }\end{array}$} & \multirow{2}{*}{$\begin{array}{c}\text { Ranks } \\
\text { 'U' test }\end{array}$} \\
\hline $\mathrm{n}=23$ & Mean & Median & St.Dev & $n=20$ & Mean & Median & St.Dev & & \\
\hline CAR 18.11.96 & 0.05 & 0.01 & 0.10 & CAR 18.11 .96 & 0.02 & 0.01 & 0.04 & 1.67 & 210.50 \\
\hline CAR 19-26.11.96 & 0.30 & 0.07 & 0.62 & CAR 19-26.11.96 & 0.07 & 0.01 & 0.17 & $1.72^{\mathrm{c}}$ & 171.00 \\
\hline CAR 27.11.96 & 0.15 & 0.07 & 0.18 & CAR 27.11.96 & 0.02 & 0.01 & 0.07 & $3.12^{\mathrm{a}}$ & $127.50^{\mathrm{b}}$ \\
\hline CAR 18-27.11.96 & 0.51 & 0.11 & 0.78 & CAR 18-27.11.96 & 0.12 & 0.01 & 0.22 & $2.30^{\mathrm{b}}$ & $160.00^{c}$ \\
\hline DISTANCE & $83,878.70$ & $62,634.00$ & $83,801.00$ & DISTANCE & $288,997.90$ & $267,007.00$ & $163,768.90$ & $-5.06^{\mathrm{a}}$ & $41.00^{\mathrm{a}}$ \\
\hline AREA & 0.09 & 0.08 & 0.06 & AREA & 0.08 & 0.06 & 0.06 & 0.92 & 181.00 \\
\hline NUMTEN & 7.13 & 7.00 & 5.32 & NUMTEN & 2.40 & 2.00 & 1.46 & $4.09^{\mathrm{a}}$ & $109.00^{\mathrm{a}}$ \\
\hline SIZE & $2,712,370.57$ & $27,108.00$ & $7,429,216.10$ & SIZE & $249,952.15$ & $10,700.00$ & $556,988.51$ & 1.58 & 181.00 \\
\hline $\begin{array}{l}\text { RISK } \\
{ }^{\text {a }} \text { Significant at the } 1 \\
{ }^{\mathrm{b}} \text { Significant at the } 5 \\
{ }^{\mathrm{c}} \text { Significant at the } 1\end{array}$ & $\begin{array}{l}1.42 \\
\% \text { level } \\
\% \text { level } \\
\% \text { level }\end{array}$ & 1.42 & 0.59 & RISK & 1.63 & 1.75 & 1.05 & -0.77 & 188.00 \\
\hline
\end{tabular}


Table 3 - Whites corrected OLS Regression models using closest distance methodology

\begin{tabular}{|c|c|c|c|c|c|c|c|c|c|c|}
\hline & & \multicolumn{4}{|c|}{ Panel A - Models Without Press } & \multicolumn{5}{|c|}{ Panel B - Models With Press } \\
\hline & & 18.11 .96 & $19-26.11 .96$ & 27.11 .96 & $18-27.11 .96$ & 18.11 .96 & $19-26.11 .96$ & 27.11 .96 & $18-27.11 .96$ & 1 Year After \\
\hline & Sign & $\mathrm{N}=43$ & $\mathrm{~N}=43$ & $\mathrm{~N}=43$ & $\mathrm{~N}=43$ & $\mathrm{~N}=43$ & $\mathrm{~N}=43$ & $\mathrm{~N}=43$ & $\mathrm{~N}=43$ & $\mathrm{~N}=43$ \\
\hline \multirow[t]{2}{*}{ Constant } & & .08 & .73 & .21 & 1.01 & .05 & .57 & .20 & .71 & -.53 \\
\hline & & (1.66) & $(3.38)^{\mathrm{a}}$ & $(3.19)^{\mathrm{a}}$ & $(3.73)^{\mathrm{a}}$ & (1.13) & $(3.01)^{\mathrm{a}}$ & $(2.93)^{\mathrm{a}}$ & $(3.08)^{\mathrm{a}}$ & $(-2.19)^{\mathrm{b}}$ \\
\hline \multirow[t]{2}{*}{ Distance } & - & -.01 & -.01 & -.01 & -.01 & -.01 & -.01 & -.01 & -.01 & .01 \\
\hline & & $(-1.50)$ & $(-2.68)^{\mathrm{a}}$ & $(-3.33)^{\mathrm{a}}$ & $(-3.24)^{\mathrm{a}}$ & $(-.96)$ & $(-2.68)^{b}$ & $(-2.92)^{\mathrm{a}}$ & $(-2.61)^{b}$ & (1.17) \\
\hline \multirow[t]{2}{*}{ Area } & + & -.19 & -.52 & .15 & -.55 & -.14 & -.34 & .05 & -.28 & .57 \\
\hline & & $(-1.05)$ & $(-.54)$ & (.45) & $(-.43)$ & $(-.78)$ & $(-.34)$ & (.14) & $(-.24)$ & (.62) \\
\hline \multirow[t]{2}{*}{ Numten } & + & .01 & -.05 & -.01 & -.05 & .01 & -.05 & -.01 & -.07 & .01 \\
\hline & & $(.20)$ & $(-2.36)^{b}$ & $(-1.32)$ & $(-2.11)^{b}$ & (.48) & $(-2.40)^{\mathrm{b}}$ & $(-1.10)$ & $(-2.65)^{\mathrm{a}}$ & (.58) \\
\hline \multirow[t]{2}{*}{ Press } & + & & & & & .04 & .02 & .05 & .04 & -.02 \\
\hline & & & & & & $(3.62)^{\mathrm{a}}$ & (1.63) & $(2.42)^{\mathrm{b}}$ & $(2.83)^{\mathrm{a}}$ & $(-2.96)^{\mathrm{a}}$ \\
\hline Adjusted $\mathrm{R}^{2}$ & & .02 & .17 & .20 & .19 & .10 & .24 & .23 & .35 & .15 \\
\hline F value & & (1.34) & $(3.75)^{b}$ & $(4.49)^{\mathrm{a}}$ & $(4.28)^{\mathrm{b}}$ & $(2.19)^{c}$ & $(4.20)^{\mathrm{a}}$ & $(4.13)^{\mathrm{a}}$ & $(6.61)^{\mathrm{a}}$ & $(2.78)^{\mathrm{b}}$ \\
\hline
\end{tabular}

${ }^{\mathrm{a}}$ Significant at the $1 \%$ level

${ }^{\mathrm{b}}$ Significant at the $5 \%$ level

${ }^{\mathrm{c}}$ Significant at the $10 \%$ level 


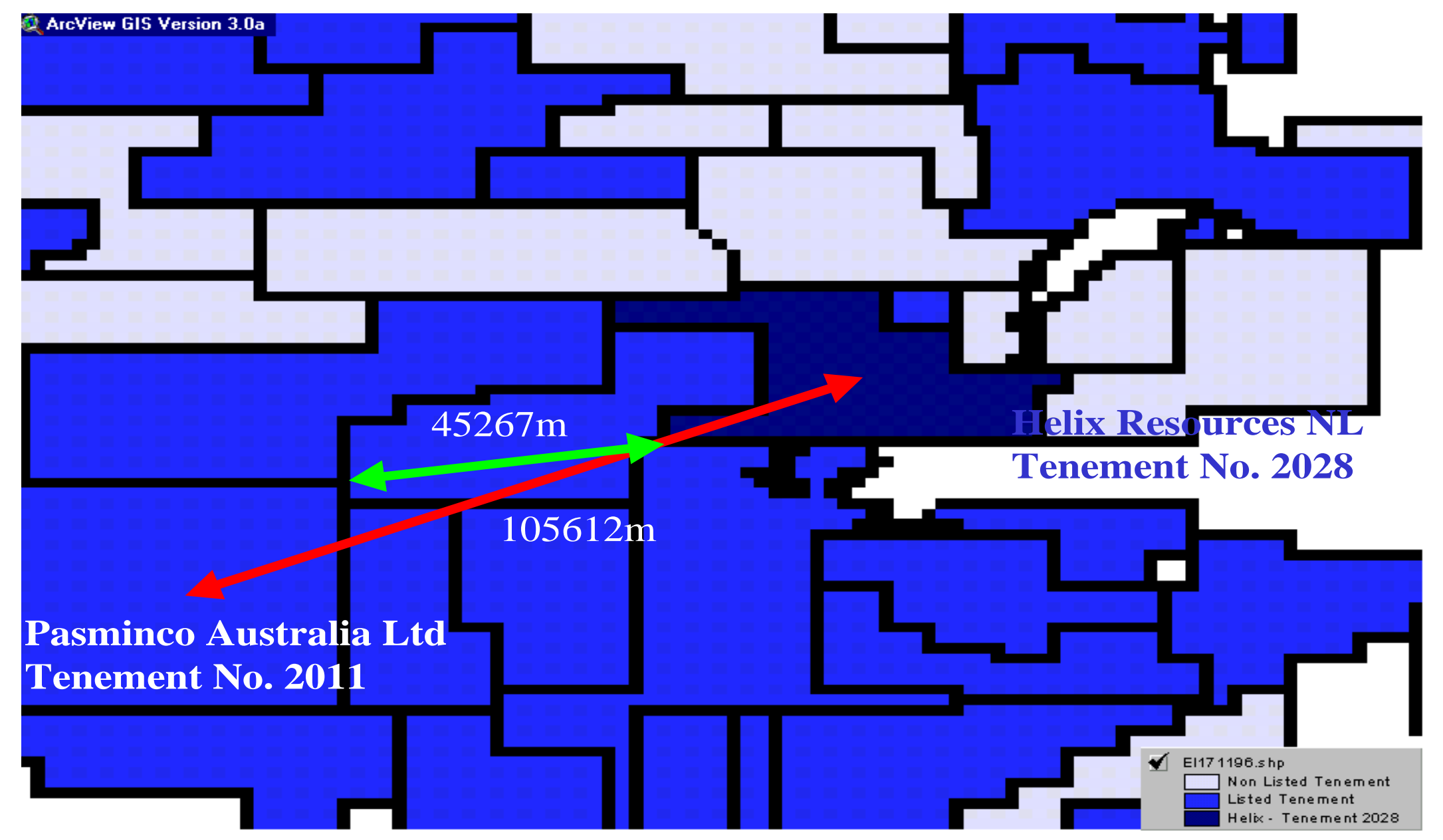

